\title{
Political Accountability in the Republic of Kosovo
}

\author{
Murat Jashari ${ }^{1}$ \\ ${ }^{1}$ Prishtina University, Faculty of Law, Kosovo \\ Correspondence: Murat Jashari, Prishtina University, Prishtina, Kosovo.
}

Received: September 18, 2017

Accepted: October 11, $2017 \quad$ Available online: October 18,2017

doi:10.11114/ijsss.v5i11.2712

\author{
URL: https://doi.org/10.11114/ijsss.v5i11.2712
}

\begin{abstract}
Political accountability is the most specific type of social accountability for the fact that it lacks a normative legal aspect and that it derives mainly from the behavior, not from an opportunistic attitude or disclosure of specific subject in relation to the expectations of the body or institution or the relevant electoral body. Political accountability is the conditio sine quo non (indispensable condition) to a democratic system of government. Hence the Kosovo Government on the merits of the constitutional aspect has accepted this institute. It is precisely this institute of political accountability that will be the topic of this paper taking into account the responsibilities of the executive government in relation to the legislative, as well as the political accountability of those elected in relation to the voters. The accountability of the President will be treated in the framework of constitutional accountability, and that of the Government in the framework of parliamentary accountability.
\end{abstract}

Keywords: Kosova, political accountability, government, constitution, president

\section{Introduction}

The notion of accountability, in different contexts, has a meaning and can be understood in different ways. Therefore, there are numerous views about this notion being of social, political or legal accountability. If we analyze in wider terms the notion of accountability we can observe that this institute is a social category, as it is installed in all spheres of society and depending on the meaning, one should keep in mind that accountability is a dynamic category of social relations and for the study of this institute there are potentially different scientific approaches such as politicological, judicial, sociological, economical, etc (Sokoli,2008: 53).

To better understand the meaning of political accountability one must first separate it from legal accountability, as under the notion of these two kinds of accountability (legal and political) and distinctive elements that exist between these two institutions, of course, there is a difference. Before dealing with the notion of political accountability one should explain that political accountability is related to the electoral process, while legal liability is related to the violation of law and order, excluding cases when legal accountability also implies political accountability.

Political accountability is the specific type of judicial accountability, the basis of which consists of "non-opportunistic work that is incompatible with the position, views and opinions or the interests of the forum or body to which it is accountable" (Stavileci, 2010: 162). Therefore, non-opportunity (non-rationality) is included in the sphere of discretion; therefore, political accountability is not legally regulated, unlike the basis of other forms of a regulated judicial accountability. The realization of political accountability made in the case of non-justifying belief holders of administrative functions, p.sh, the ministers by their constituent. The realization of political accountability is made in the case of non-justifying trust on holders of administrative functions, such as the ministers by their constituents.

Despite authors who separate political accountability from the legal accountability, one may even face situations where political accountability may also have the character of legal accountability in cases when a subject has violated relevant legal norms which order the entities designated to implement the policy in a particular manner and under the procedure prescribed. This is the case when political accountability may also bear legal accountability as one is dealing with a violation of ordinance from the designated entity. Another situation of political accountability appearing as extra-judicial accountability may be when it comes to subjects who by their own actions in carrying out task entrusted to them have not violated the legal norms concerning the exercise of political power, but have rather violated other social norms, such as political, moral or similar.

Political accountability can be raised as individual accountability of elected officials or political appointees, but also as 
a collective political accountability policy, primarily of the collective bodies of government, such as state Presidencies (Switzerland, Bosnia and Herzegovina, etc.), and governments or political party presidencies. While respecting this breakdown, here we are only considering the political accountability of the executive branch in the Republic of Kosovo, namely the Government and the President in relation to the Parliament, and also the accountability of the elected political appointees in relation to the citizens.

In the first case one relies on the principle of separation of powers, within which one finds the political accountability of the executive vis-à-vis the legislative, whereas in the second case one relies on the relation between the constituents and the elected.

The Constitution of the Republic of Kosovo has defined the political accountability as a constitutional category, with its Article 4 defining Kosovo as a democratic Republic based on the principle of separation of powers and checks and balances between them. This separation of powers is meant as checks and balances of these powers, as well as the other meaning with each power being accountable towards the other authority.

\section{Political Accountability - Legal Regulation of the Institute under the Constitution of the Republic of Kosovo}

As in most parliamentary systems of governance, in the Republic of Kosovo too the central state powers are divided among the legislative, executive and judiciary. Under this principle stems the institute of accountability as the three powers in some form are accountable to each other. Therefore, referring to the principle of separation of powers, the institute of accountability in Kosovo will be handled from a horizontal view, because, according to this constitutional principle, as horizontal accountability stems of one power against the other stems from it.

Initially referring and analyzing Article 4 of the Constitution of the Republic of Kosovo, which states that "Kosovo is a democratic Republic based on the principle of separation of powers and the checks and balances among them," (Kosovo Constitution, 2009) one implies that in our country the institute of accountability and the balancing of powers has been installed with constitutional provisions, which means that various organs have the power to decide on the same field-activity and can block decisions of each other through different mechanisms of exercising control and accountability institute. So, as in all democratic countries, in the Republic of Kosovo is an element of checks and balances of powers is installed as an essential prerequisite of democracy, with the importance of the mechanism "lying in creating a system of checks and balances as such a system should ensure in democratic countries political stability and mutual cooperation between state bodies and institutions", (Bajrami, 2010: 85). However, one has to keep in mind that, although with parliamentary atypical elements, (Jashari and Selimi,2016: 134-145) the Republic of Kosovo is a state with a parliamentary system of governance and in this context, our country's government is elected by the Assembly and the Assembly is the highest organ of the state power which establishes and controls all other organs of governance.

Basically, the principle of separation and balance of powers, "relations between the legislative and the executive are based on their independence and reciprocal control, which includes the right of veto, the right to dissolve the parliament by the President, or the ability of the Parliament to exercise political and constitutional accountability over the President in its turn",(Bajrami,2010: 86). One may say that this separation and balance of powers is "a rigid separation" of powers meaning that such a division was not installed with the constitutional provisions of the Republic of Kosovo, as this division has been rather practiced in states with a presidential system of governance.

One may say that in the Republic of Kosovo there is a "soft division" of powers between the legislative and executive for the Assembly of Kosovo has an accentuated advantage with regard to the executive, a power which is exercised by the Government and the President under powers delegated by the Constitution as the President as acting executive power together with the Prime Minister are unable to stand against the Parliament with a motion opposing its early dissolution lacking an absolute veto right. While the Assembly, under the constitutional provisions has the right to elect and dismiss the President of the Republic and to elect and motion for no confidence vote over the Government (Kosovo Constitution, Articles 65.7 and 65.8)

Actually, according to Article 84.6 of the Constitution of the Republic of Kosovo, the President "has the right to return adopted laws for re-consideration, when he/she considers them to be harmful to the legitimate interests of the Republic of Kosovo or one or more Communities. However, this right can be exercised only once per law"(Idem, Article 84.6). However, the Assembly decides to adopt a law returned by the President of the Republic and such a law is considered promulgated (Idem, Article 80.4). It means that according to the accountability system installed in the Republic of Kosovo, the executive authority (Prime Minister and President) is elected by the Assembly and one can say that it is "an executive body of the Assembly", which can exercise the issue of accountability of the executive before the legislative at any time by using the constitutional powers through the institute of non-confidence over the Government, adoption of the budget, the deputies' questions, interpellations, or even on the basis of the creation of ad hoc commissions to clarify the facts proving political accountability of the Government as a whole or any of its ministries. 
Meanwhile, the Assembly of the Republic of Kosovo can raise the issue of political accountability of the President almost at any time because it relates to his election and dismissal by the Assembly. Hence, according to Article 91 of the Constitution of the Republic of Kosovo, the President of the Republic of Kosovo may be dismissed by the Assembly with the two-thirds $(2 / 3)$ of votes of all members if the President has been convicted of a serious crime or when the Assembly determines that the President is not capable of exercising his/her duties due to serious illness or if the Constitutional Court has determined that he/she has committed a serious violation of the Constitution. According to Article 91.2 of the Constitution of the Republic of Kosovo the procedure on the dismissal of the President of the Republic of Kosovo may be initiated by one third (1/3) of deputies of the Assemblies who sign a petition explaining the reasons for dismissal. If the petition alleges serious illness, the Assembly would request the opinion of the Medical Council at the President's health condition. If the petition alleges serious violation of the Constitution, the petition shall be immediately submitted to the Constitutional Court, which shall decide the matter within seven (7) days of receipt of the petition.

It is worth mentioning that in the Republic of Kosovo since the declaration of independence in 2008 till to date there has been no case of dismissal of the President by the Assembly as a result of political accountability. The only case of political accountability of the President was the case in 2010 regarding then-President Fatmir Sejdiu, in which a request was initiated by members of the Assembly to the Constitutional Court in order to determine whether the President had violated the Constitution or not. The object of this request was that the President was holding to positions at the same time, that of the President and Chairman of a political party, running counter to Article 88.2 of the Constitution,( The Decision of the Constitutional Court, case no.cl 47/10, dated 28 September 2010). In this case, the Constitutional Court found a violation of the Constitution by the President and the judgment read as follows: "... there has been a serious violation of the Constitution of the Republic of Kosovo, respectively Article 88.2 of the Constitution, by His Excellency, Mr. Fatmir Sejdiu, while keeping the post of the President of the Republic of Kosovo and the position of the political party, the Democratic League of Kosovo." After the verdict, the then President resigned as a result of political accountability avoiding a consideration of the question by the Assembly under Article 91 of the Constitution relating to the procedure of dismissal of the President.

Also, with reference to Article 4 of the Constitution of the Republic of Kosovo, one can elaborate on the accountability of the Government. Under this constitutional provision, the Government of the Republic of Kosovo is responsible for implementation of laws and state policies and is subject to parliamentary control, which means that the Government of the Republic of Kosovo is elected by the Assembly and is also subject to parliamentary control under the institutes of this form of control. Also, referring to Article 92 of the Constitution of the Republic of Kosovo, the Government exercises executive power, meaning it implements laws and other acts passed by the Assembly of Kosovo and exercises other activities within the limits of the Constitution and law, where under this activity, the Government proposes draft laws and amendments to existing laws and other acts and may give its opinion on draft laws that are not proposed by it. Regarding its complete activities within the powers that are given by the Constitution and other laws, the Government, for its work, is responsible only to the Assembly of Kosovo. The Prime Minister, Deputy Prime Ministers and ministers bear the responsibility for the decisions made by the Government and individually account for decisions made in their fields of responsibility. So, this constitutional provision provides shared responsibility under the theory that all ministers are obliged to provide public support for government policies as a form of accountability of the Government as a whole. Meanwhile, another doctrine also means that ministers are responsible for the actions (mistakes) of their civil employees as a form of individual ministerial responsibility. In this context, the Assembly of the Republic of Kosovo, may raise the question of responsibility of the government as a whole or for any minister in particular by applying the institute of control and accountability through budget approval, periodic reports of the Government before the Assembly, parliamentary interpellation, MPs' questions, no-confidence motion of the government and ad hoc commissions created on a particular issue.

\section{Relevance of Political Responsibility to the Sovereign - the Case of the Republic of Kosovo}

In advanced countries, in different contexts, disciplinary, material, misdemeanor, administrative, civil, criminal and even political accountability is known and mainly applied.

While different types of responsibilities are recognized and, to some extent respected, the political accountability is a specific ratio between officials of elected or appointed bodies and political institutions on the one hand and voters and their denominators and constituents creators, on the other. Political accountability in the political relation between elected and the appointed refers primarily to officials, bodies, forums and, generally, institutions elected, appointed or constituted for the exercise of political functions as mandated in the face of voters denominators, constituents as their mandate givers.

Political accountability seems to represent the relation and position of obliging elected or appointed officials, bodies, 
forums and, generally, institutions constituted for the exercise of political functions as mandated in the face of those who gave them the mandate, i.e. those who elected, appointed or constituted them, namely those in the name and interest of which they function politically. The range of the institution's legal political accountability, initially consist promises public bid to win political mandates and, therefore, work and political activities in the consistent with political offers, activities and political acts adopted, the (free) embodied in political operation. The range of the legal institution of political accountability, initially consists of public promises as offerings to gain political mandates and, therefore, functions and political activities in accordance with political bids political with activities and political acts passed, and embodied during the political functioning.

Referring to the policies, political activities and acts during political mandates, special emphasis is addressed to the adaptability with (programs) offers and their political effectiveness. However, the tone of the content of political responsibility, would have to give the premise of morality and legality. The tone of the content of political accountability should be set on the premise of morality and legality. Even when public political promises will be realized as a bid for the confidence of the political mandate, should not be contrary to the principles of morality and legality.

In such cases, the respective nominees of political functions, by no means and in no way can be pardoned from political responsibility. Such an outcome in Kosovo's political practices is rather unrecognized. Public megalomaniac promises in election campaigns serve the candidates for public offices only to win the mandatory votes and then, even publicly, the same point out that those promises belong to the election rhetoric and, as such, represent no obligation for them. However, public promises anywhere and anytime, even by basic postulates of civil law and, sooner and rather, according to moral principles, however, creates a legal and political relationship of which obligations arise sanctioned for the respective promised subject. Therefore a coherence of public promises has to be pursued, degree and quality of their realization and, appropriately, an evaluation has to be done, for better or for worse, refe rring to political office holders. Furthermore, this evaluation, in our country, except in theory, is almost nonexistent in practice, so the political heads in our country, with some exceptions, are irresponsible and arbitrary.

Political accountability does not prejudge the existence of disciplinary, material, moral, civil, administrative or criminal accountability. Rather, the political accountability should be complementary to any form of legal liability respectively.

Defining and implementing the political accountability depends both on the political and constitutional system and the legal order of the particular state. In any modern democratic state political accountability is determined normatively and accomplished virtually in the context of its type, as democratic or autocratic, monocratic or Republican, one party or multi-party and, generally, and in regard to the existence of the rule of law (not the "state of law" for such a state may be autocratic and anti-democratic), with full and harmonized legal order, having effective institutions for its implementation with firmness and consistency.

It is not easy to develop a political discourse on the accountability while it beforehand is not clearly defined by the legal acts of political parties, and sanctioned as such. Consequently, the procedure of realization of political accountability at all levels and cases should be sanctioned. It is precisely for this that a Law on political accountability (which we do not have) should oblige entities and all political institutions to legally sanction political accountability and its procedures (with political programs, statutes and internal organization acts). Subsequently, thanks to the political good and sufficient will, a concrete application of political accountability should be ensured, depending on the specific circumstances starting with a warning admonition and continuing with public admonition, revocation and dismissal from public and political position and function.

\section{Conclusion}

Drawing from the entire exposition and analysis of the notion of political accountability in general and the application of this institute in the Republic of Kosovo in particular, one may conclude the following:

- Political accountability is part of democratic culture as democracy is a political system of accountability, given that a democratic society builds its power system and political institutions under the accountability of everyone and all, including bearers of highest functions of the state.

- In legal terms, it is understood that each legal system possesses a system of accountability which should ensure the effectiveness of that system. In this sense the political accountability under the constitutional principles of the Republic of Kosovo has been discussed, and one may conclude that in our country, the Executive (Government in general and President) is a "body of the Assembly" as it is elected and controlled by the latter and this context one may say that in Kosovo Parliamentary accountability is more evident, as according to the provisions of the Constitution of the Republic of Kosovo, the political accountability represents an obligation for the Executive to be held liable for their work to the Parliament and that the latter may raise the issue of 
accountability of the Executive (Government in general and President) almost at every time using institutes of parliamentary oversight, which due to political accountability in the Republic of Kosovo may take legal control and supervision.

- Political accountability according to political studies can be understood as representing the foundation of a country's political system as this institution constitutes a constituent element and an integral part of the political system. Under this approach, within the political system an accountability system which conforms to the principles of that system is built. In this context it is argued in the paper that political accountability differs from one country to another, and such a difference depends on the system of the government of the country concerned and the legal regulation of this institution with constitutional or other legal acts.

- In addition one may conclude that as a criterion on the basis of which the extent to which a political format is regarded as democratic and political accountability is the accuracy and speed with which the government responds to changes in public opinion. Hence, the ability to respond to the public requires accountability of the elites, which in this context one can say that political responsibility is created also by the media as they too produce public opinion.

\section{References}

Bajrami, A. (2010).Parlamentarizmi - Aspekte krahasuese, Prishtina.

Constitution of the Republic of Kosovo, 2009

Decision by the Constitutional Court of the Republic of Kosovo on "Naim Rrustemi and 31 other members of the Assembly of the Republic of Kosovo vs. His Excellency Mr. Fatmir Sejdiu, President of the Republic of Kosovo", No.Ref.AGJ 43/10, case no.cl 47/10, Prishtina 28.09.2010.

Decision by the Constitutional Court, Case no.cl 47/10, dated 28 September 2010.

Jashari, M., \& Selimi, B. (2016). Kosovo - An Atypical Parliamentary Republic, Academicus. International Scientific Journal, 14, 136-145. http://dx.medra.org/10.7336/academicus.2016.14.07

Sokoli , A.(2009).Kontrolli i punës së administratës dhe përgjegjësia e saj politike, Prishtina.

Stavileci, E. (1997).Hyrje në shkencat administrative, Prishtina.

Stavileci, E. (2010).Fjalor shpjegues i termave administrativë, Prishtina.

The Concise Oxford Dictionary of Politics, Oxford University Press, 1996.

\section{Copyrights}

Copyright for this article is retained by the author(s), with first publication rights granted to the journal.

This is an open-access article distributed under the terms and conditions of the Creative Commons Attribution license which permits unrestricted use, distribution, and reproduction in any medium, provided the original work is properly cited. 